\title{
Transcriptional Response of MxA, PKR and SOCS3 to Interferon-Based Therapy in HCV Genotype 4-Infected Patients and Contribution of p53 to Host Antiviral Response
}

\author{
N. Hamdi ${ }^{a}$ W. El-Akel ${ }^{b} \quad$ M. El-Serafy ${ }^{b} \quad$ G. Esmat ${ }^{b} \quad$ C. Sarrazin ${ }^{c} \quad$ A.I. Abdelaziz ${ }^{a}$ \\ ${ }^{a}$ The Molecular Pathology Research Group, The German University in Cairo; ${ }^{b}$ Department of Tropical Medicine \\ and Hepatology, Cairo University, Cairo, Egypt; ${ }^{~}$ Department of Internal Medicine 1, Johann Wolfgang Goethe \\ University Hospital, Frankfurt, Germany
}

\section{Key Words}

Hepatitis $C$ virus $\cdot$ Genotype $4 \cdot$ Interferon- $\alpha \cdot$ Peripheral blood mononuclear cells $\cdot$ Myxovirus-resistance protein A - Double-stranded RNA-activated protein kinase Suppressor of cytokine signaling $3 \cdot \mathrm{p} 53$

\begin{abstract}
Aims: To investigate the myxovirus-resistance protein $A$ $(\mathrm{M} \times \mathrm{A})$ and double-stranded RNA-activated protein kinase (PKR) genetic response to interferon (IFN) therapy in hepatitis $C$ virus (HCV) genotype 4-infected patients. Moreover, we studied the association between suppressor of cytokine signaling 3 (SOCS3) gene expression and therapy resistance in genotype 4. Finally, we investigated the novel link between p53 and IFN-stimulated genes (ISGs) in humans. Methods: Gene expression analyses were performed in peripheral blood using TaqMan real-time PCR. Virologic response was assessed with a branched-DNA assay. Genotyping was confirmed. Results: Early virologic responders (EVRs, $n=23$ ) but not non-EVRs $(n=7)$ showed strong upregulation of PKR at week 12 of therapy compared to baseline. Both EVRs and non-EVRs showed MxA upregulation at week 12 compared to baseline. Baseline SOCS3 expression did not distinguish EVRs from non-EVRs in genotype 4. An association was found between p53 and MxA and PKR gene expression. Conclusion: Measurement of MxA and PKR transcriptional in-
\end{abstract}

\section{KARGER}

Fax +41613061234 E-Mail karger@karger.ch www.karger.com (c) 2011 S. Karger AG, Basel

$0300-5526 / 12 / 0553-0210 \$ 38.00 / 0$

Accessible online at:

www.karger.com/int duction during treatment may distinguish EVRs from nonEVRs in genotype 4. SOCS3 gene does not seem to be implicated in therapy resistance in genotype 4 . An association between $\mathrm{p} 53$ and ISGs expression was shown for the first time in HCV-infected patients, further supporting the contribution of $\mathrm{p} 53$ to host antiviral response.

Copyright $\odot 2011$ S. Karger AG, Basel

\section{Introduction}

Hepatitis C virus (HCV) infection has become a major disease burden on the world; 170 million people are infected worldwide and 3-4 million persons are newly infected each year [1]. The highest HCV prevalence worldwide (15\%) has been reported to be in Egypt [2], where almost $90 \%$ of HCV infections are caused by HCV genotype $4[3,4]$. The current standard treatment for chronic $\mathrm{HCV}$ infection is pegylated interferon (IFN)- $\alpha$ associated with the oral antiviral drug ribavirin given for 24 or 48 weeks depending on the genotype [5]. This regimen showed the best results in patients with genotype 2 or 3 but less promising results in patients infected with genotype 1 [6-8]. Only a few data have been published concerning genotype 4 , which is the focus of the present study, and this genotype has been classified under 'difficult-to-treat' genotypes. IFN- $\alpha$ mediates its antiviral ef- 
fects by binding to its specific IFN type 1 receptors, which results in the activation of the Janus-activated kinase (JAK)-signaling transducers and activators of transcription (STAT) (JAK-STAT) signaling pathway. Activation of the JAK-STAT pathway results in activation of a transcription activation complex (IFN-stimulated gene factor 3, ISGF3) leading to transcriptional induction of several IFN-stimulated genes (ISGs) with antiviral activity [9, 10]. Among these ISGs, the genes coding for the myxovirus-resistance protein $\mathrm{A}(\mathrm{MxA})$ and the double-stranded RNA (dsRNA)-activated protein kinase (PKR) play an important role in the host immune response against HCV. MxA protein plays a major role in host defense against viral infections by inhibiting viral replication through its GTPase activity [11]. Furthermore, MxA gene expression is rapidly induced upon viral infection and tightly regulated by type 1 IFNs $[12,13]$. In addition, MxA expression requires STAT1 signaling as recently demonstrated in human STAT1 null cells [14]. Thus, $\mathrm{MxA}$ is a sensitive and reliable marker for type 1 IFN bioactivity and is suitable for gene expression studies [15].

PKR protein kinase is activated in response to dsRNA and thus acts as a sensor of viral infections [16]. Its activation leads to the phosphorylation of the $\alpha$-subunit of the eukaryotic initiation factor (eIF-2 $\alpha$ ) [17], resulting in general inhibition of translation, including translation of viral mRNA [18]. It has recently been demonstrated that PKR protein kinase is activated by HCV infection and plays a critical antiviral role through inhibition of viral protein translation [19]. Thus, analysis of MxA and PKR gene expression would be a practical approach to assess the individual molecular efficacy of the currently used combination therapy, especially in genotype 4 , which has not been previously investigated on the molecular level.

On the other hand, suppressors of cytokine signaling (SOCS) have been identified as regulators of JAK-STAT signaling by acting through a classical negative feedback loop [20]. The role of the suppressor of cytokine signaling 3 (SOCS3) in the resistance to IFN-based therapy in HCV infection has recently been evoked. Recent in vitro studies have demonstrated that a high level of SOCS3 was found in HCV-replicating cells which were resistant to IFN therapy [21] and that induction of SOCS3 was induced by HCV core protein and resulted in impaired IFN signaling [22]. The inhibitory effect of SOCS3 on the JAK-STAT pathway has been shown to be mediated by a reduction in STAT1 phosphorylation [23]. Recent in vivo studies have demonstrated a positive correlation between high pretreatment SOCS3 gene expression and nonresponse to therapy in genotype 1-infected patients both in the liver as well as in peripheral blood mononuclear cells (PBMCs) [23-25]. However, to our knowledge, the role of SOCS3 in the response to treatment of HCV genotype 4-infected patients has not been previously investigated.

The tumor suppressor gene $\mathrm{p} 53$ has recently been classified under type 1 IFN-induced genes because of the presence of active IFN-stimulated response elements in its promoter [26]. Very recently, Dharel et al. [27] showed that p53 had an inhibitory effect on HCV replication in HCVreplicating cell lines and they reported an interaction between p53 and the IFN regulatory factor 9 (IRF9). IRF9 is one of the components of the IFN-stimulated gene factor 3 (ISGF3) which is necessary for transcription activation of ISGs through the JAK-STAT pathway. The interaction of $\mathrm{p} 53$ with the IFN- $\alpha / \beta$ pathway was further investigated by Munoz-Fontela et al. [28], who showed a p53-dependent transcriptional activation of IRF9 in vitro as well as in infected mice. So far, no in vivo studies have investigated the role of p53 in antiviral defense in humans.

In the present study, MxA and PKR expression was analyzed at the transcriptional level in patients infected with HCV genotype 4. In addition, the relationship between the virologic response and the expression of $\mathrm{MxA}$ and PKR was also studied in order to clarify the relationship between the clinical outcome of combination therapy and the transcriptional response to IFN in genotype 4 . Furthermore, the SOCS3 mRNA level was correlated with the virologic response of HCV genotype 4-infected patients in order to investigate the role of SOCS3 in resistance to therapy in genotype 4 . On the other hand, the role of p53 in host antiviral defense has been investigated for the first time in HCV-infected humans. The use of PBMCs made it possible to perform the current gene expression study both at the baseline level as well as 12 weeks after initiation of the therapy with pegylated IFN$\alpha$ associated with the oral antiviral drug ribavirin, which represents the first important milestone in the assessment of treatment response and decides on the interruption of therapy in patients who do not achieve at least a $2-\log _{10}$ decrease in their baseline viral load.

\section{Patients and Methods}

\section{Patients}

Subjects were adult patients (mean age $39 \pm 16$ years), with chronic hepatitis C, who were treated at the Viral Hepatitis Treatment Center (VHTC) in Al Kahera Al Fatymia Hospital in Cairo during the years 2008 and 2009. All patients were HCV RNA positive and all patients were negative for hepatitis B surface antigen. After written informed consent was obtained from patients, serum 
and peripheral whole-blood samples were collected before initiation of therapy and genotyping was performed (Versant HCV Genotype 2.0 Assay; Siemens Medical Solution Diagnostics; formerly Bayer HealthCare). In order to standardize the viral RNA quantification method, the branched DNA (bDNA) assay (Versant HCV RNA 3.0 Assay; Siemens Medical Solution Diagnostics) was used to document the baseline viral load and assess the viral load decline during treatment. According to the genotyping results and the baseline HCV RNA, 38 patients with detectable viral RNA were eligible to be included in this study. Among these patients, 30 had genotype 4 and 8 patients had either other genotypes than genotype 4 or genotyping results were unspecific. Only patients having genotype 4 were included in the gene expression study of $\mathrm{MxA}$, PKR and SOCS3. For the gene expression study of p53, all 38 patients were considered. A group of sex- and age-matched healthy volunteers were also included in this study as controls after informed consent. PBMCs were extracted and baseline gene expression analyses of MxA, PKR, SOCS3 and p53 were performed using the TaqMan real-time PCR technique. Patients started treatment with pegylated IFN- $\alpha-2 \mathrm{a}$ at a dose of $180 \mu \mathrm{g}$ weekly by subcutaneous injection associated with ribavirin orally at a dose of $1,000 \mathrm{mg}$ if the body weight was less than $75 \mathrm{~kg}$ and $1,200 \mathrm{mg}$ if the body weight was equal to or greater than $75 \mathrm{~kg}$. Serum and peripheral blood samples were again collected after 12 weeks of therapy. Viral RNA was again quantified using the same bDNA assay for the assessment of early virologic responders (EVRs) and PBMCs were isolated for the gene expression analyses of PKR, MxA, SOCS3 and p53 at week 12 of therapy. All experiments were performed in compliance with the guidelines of the institutional review board of Kasr El Aini Medical School in Cairo University and in accordance with the ethical standards of the Declaration of Helsinki.

\section{Preparation of PBMCs}

PBMCs were isolated from $2 \mathrm{ml}$ venous blood using the Ficoll density gradient centrifugation method and resuspended in $1 \mathrm{ml}$ freeze mix (RPMI-1640 medium supplemented with antibiotics, FBS $30 \%$, DMSO 10\%) and immediately frozen at $-80^{\circ}$ until use.

\section{Isolation of Total Cellular RNA}

Total cellular RNA was extracted from PBMC pellets using the QIAamp RNA Blood Mini kit (Qiagen, Hilden, Germany) following the manufacturer's instructions. The extracted RNA was stored at $-20^{\circ}$ until use.

\section{cDNA Preparation}

Total cellular RNA was reverse transcribed into single-stranded complementary DNA (cDNA) using the High-Capacity cDNA Reverse Transcription kit (Applied Biosystems, Foster City, Calif., USA) following the manufacturer's instructions. The synthesized cDNA samples were stored at $-20^{\circ}$ until use.

\section{Analysis of Gene Expression by the TaqMan Real-Time PCR}

Technique

The mRNA expression level of the studied genes MxA, PKR, p53 and SOCS3 as well as of the housekeeping gene GAPDH, used as internal control, was quantified using TaqMan real-time PCR using the StepOne ${ }^{\mathrm{TM}}$ Real-Time PCR instrument (Applied Biosystems) and StepOne ${ }^{\mathrm{TM}}$ system software (Applied Biosystems). In order to quantify the results obtained by the real-time PCR, the comparative cycle threshold (CT) method was used comparing the CT values of the samples of interest with healthy controls. The CT values of both the calibrator and the samples of interest were normalized to the CT values of the endogenous housekeeping gene GAP$\mathrm{DH}$ in the same sample. The experiments were done in duplicate and the results expressed in relative quantitation, $R Q=2^{-\Delta \Delta C T}$.

\section{Genotyping}

Following viral RNA extraction, using the QIAamp Viral RNA Mini Kit (Qiagen), reverse transcription and PCR amplification were performed using the Versant HCV Amplification 2.0 Kit (Siemens Medical Solution Diagnostics). DNA PCR products were then processed using the Versant HCV Genotype 2.0 Assay (LiPA; Siemens Healthcare Diagnostics) according to the manufacturer's instructions.

\section{Quantification of Viral RNA}

Quantification of viral RNA in the serum prior to the commencement of the treatment as well as at week 12 of therapy has been performed using the Versant HCV RNA 3.0 Assay (HCV 3.0 bDNA assay; Bayer Diagnostics) following the manufacturer's instructions. The dynamic linear quantification of the HCV RNA 3.0 assay ranges from 615 to $7.7 \times 10^{6} \mathrm{IU} / \mathrm{ml}$.

Data Analysis

Gene expression is expressed in relative quantitation $(\mathrm{RQ}=$ $\left.2^{-\Delta \Delta C T}\right)$ and data are expressed as mean \pm standard error of the mean (SEM). An unpaired Student t test was used to compare gene expression between patients and healthy controls as well as between EVRs and non-EVRs as a response to combination therapy. A p value $<0.05$ was considered statistically significant. Correlations were studied using Pearson's correlation. Calculations were performed using the GraphPad Prism software, version 5.00.288 (GraphPad Software, Inc.)

\section{Results}

\section{Response to Treatment}

Among the 30 patients infected with genotype 4, 23 (76.66\%) had at least a 2 -log decrease in their baseline viral load after 12 weeks of therapy and were classified as EVRs while only 7 (23.34\%) showed either no decline or a decline less than 2 logs in their basal viral load at week 12 and were classified as non-EVRs. Furthermore, among the EVRs $(\mathrm{n}=23), 86.95 \%(\mathrm{n}=20)$ showed an undetectable viral RNA level in the serum at week 12 (complete EVRs), while $13.05 \%(n=3)$ achieved only a 2-log decrease in their viral load at week 12 (partial EVRs). Follow-up after 24 weeks of therapy showed that 19 out of 20 (95\%) complete EVRs had a negative qualitative PCR at week 24 of therapy.

\section{MxA mRNA Expression in PBMCs}

MxA mRNA level was analyzed in PBMCs of patients with chronic HCV genotype 4 and healthy controls. It was 


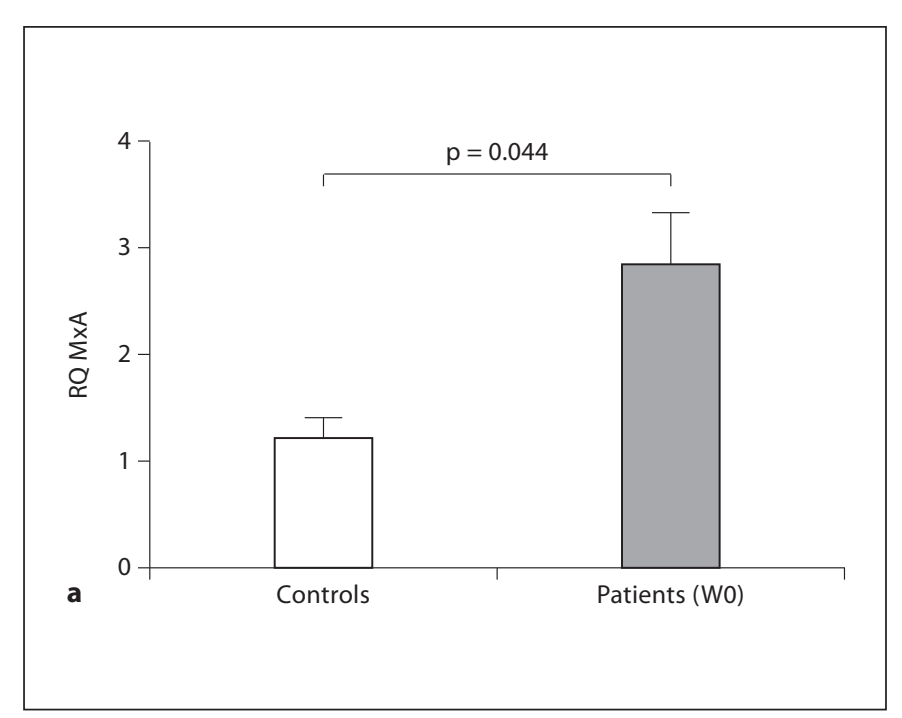

Fig. 1. MxA mRNA expression in PBMCs before and during treatment. a Significant 2.3-fold upregulation of baseline MxA in patients $(2.848 \pm 0.4881, \mathrm{n}=30)$ compared to controls $(1.217 \pm$ $0.191, \mathrm{n}=12) ; \mathrm{p}=0.044$. $\mathbf{b}$ Upregulation of baseline MxA gene expression in both EVRs $(2.977 \pm 0.6082, \mathrm{n}=23)$ and non-EVRs $(2.426 \pm 0.6639, \mathrm{n}=7)$ compared to controls $(1.217 \pm 0.191, \mathrm{n}=$ $12) ; p=0.0485$ and 0.0446 , respectively. There is no statistically significant difference in MxA gene expression between EVRs and non-EVRs ( $p=0.6416)$. Strong MxA upregulation in EVRs at

shown that the baseline level of MxA mRNA expression before treatment initiation was significantly upregulated in patients compared to healthy controls (mean upregulation 2.3-fold; $p=0.044$; fig. 1a). Both EVRs and non-EVRs showed a significant baseline MxA mRNA upregulation compared to healthy controls without a significant difference between EVRs and non-EVRs (fig. 1b). Interestingly, a strong upregulation in MxA mRNA expression level was observed in EVRs at week 12 compared to their MxA mRNA expression level before treatment $(p<0.0004)$, whereas only a moderate upregulation was found in nonEVRs between week 0 and week 12 ( $\mathrm{p}=0.0341$; fig. $1 \mathrm{~b})$.

\section{PKR mRNA Expression in PBMCs}

Baseline PKR gene expression showed no significant statistical difference between healthy controls and untreated HCV genotype 4-infected patients (fig. 2a). Both EVRs and non-EVRs did not show significant upregulation of their baseline PKR gene expression compared to healthy controls (fig. 2b) with no significant difference between EVRs and non-EVRs (fig. 2b). EVRs showed a significant upregulation of PKR gene expression at week 12 compared to week 0 ( $\mathrm{p}=0.0332)$; whereas non-EVRs

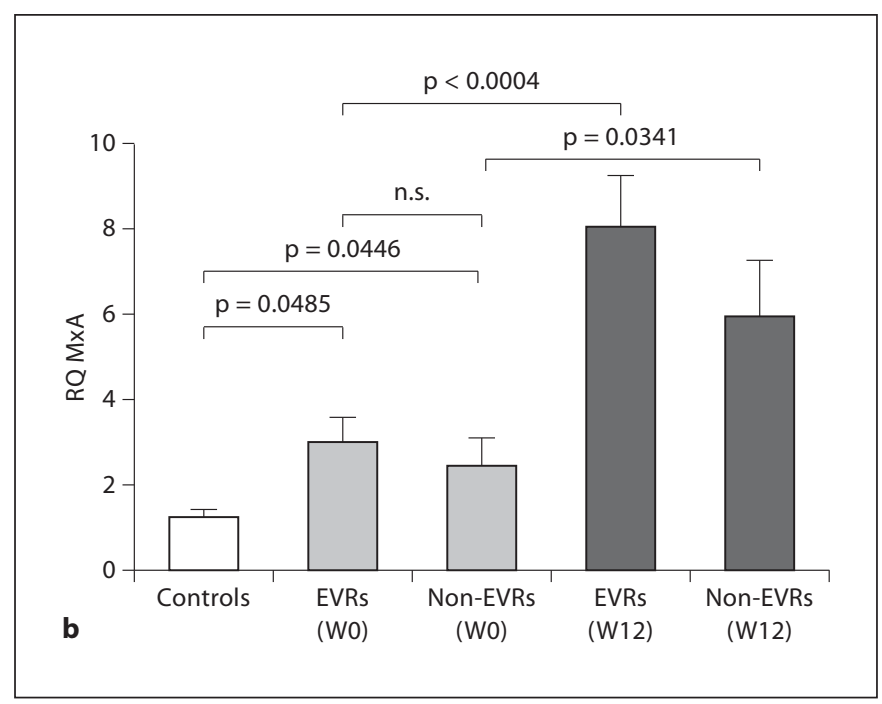

week $12(\mathrm{~W} 12)(8.072 \pm 1.171, \mathrm{n}=23)$ compared to week 0 (W0) $(2.977 \pm 0.6082, \mathrm{n}=23) ; \mathrm{p}<0.0004$. Non-EVRs show only a moderate, but statistically significant, upregulation at week $12(5.943$ $\pm 1.312, \mathrm{n}=7)$ compared to week $0(2.426 \pm 0.6639, \mathrm{n}=7) ; \mathrm{p}=$ 0.0341 . There is no significant difference between EVRs (8.072 \pm $1.171, \mathrm{n}=23)$ and non-EVRs at week $12(5.943 \pm 1.312, \mathrm{n}=7) ; \mathrm{p}=$ 0.3539 . The results are expressed as means \pm SEM of relative quantitation $\left(R Q=2^{-\Delta \Delta C T}\right)$. Bar $=$ Mean value.

showed no significant upregulation in PKR gene expression at week 12 compared to week $0(\mathrm{p}=0.8799$; fig. $2 \mathrm{~b})$.

\section{Coordinate Upregulation of $M x A$ and $P K R$}

Baseline level of MxA mRNA expression was correlated to baseline level of PKR mRNA expression within the same sample. A statistically significant positive correlation was found between baseline gene expression of MxA and PKR ( $p=0.0002, r=0.633)$, indicating that the activated IFN- $\alpha / \beta$ pathway induced a coordinate upregulation of MxA and PKR genes (fig. 3).

\section{SOCS3 mRNA Expression in PBMCs}

Baseline SOCS3 gene expression was upregulated in patients compared to controls (fig. 4a). Both EVRs and non-EVRs showed a significant upregulation of baseline SOCS3 gene expression compared to healthy controls ( $\mathrm{p}=0.0303$ and 0.0312 , respectively) without a significant difference between EVRs and non-EVRs (fig. 4b). After 12 weeks of therapy, SOCS3 mRNA expression showed no significant increase compared to week 0 in both EVRs and non-EVRs (fig. 4b). Relative changes in SOCS3 gene expression between week 0 and week 12 were also com- 


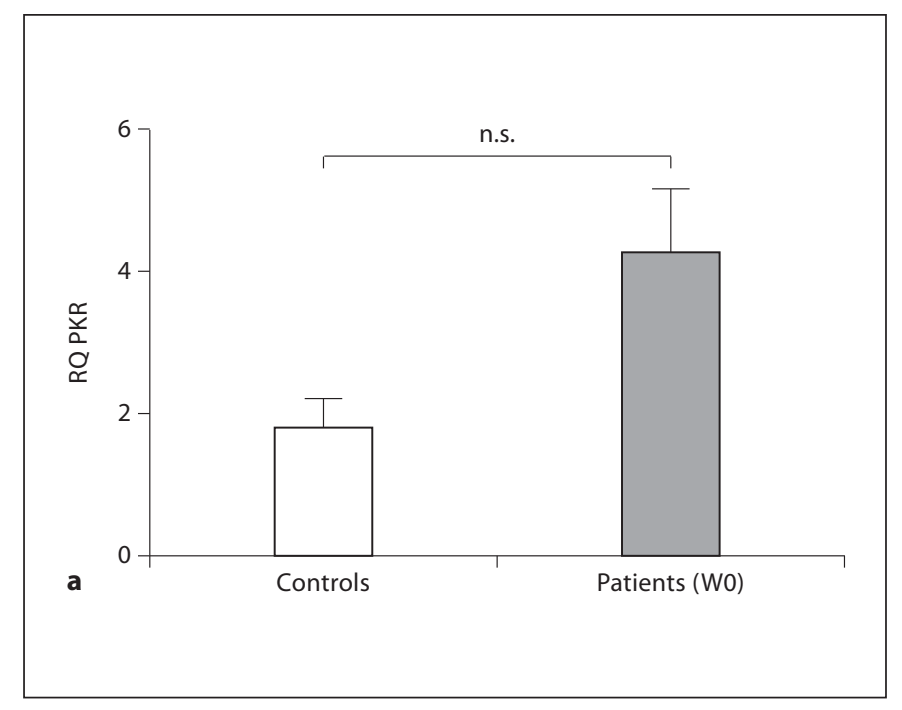

Fig. 2. PKR mRNA expression in PBMCs before and during treatment. a Baseline PKR expression does not significantly differ between $\mathrm{HCV}$ patients $(4.266 \pm 0.8885, \mathrm{n}=30)$ and healthy controls $(1.805 \pm 0.4038, \mathrm{n}=12) ; \mathrm{p}=0.0947$. b There is no statistically significant upregulation of baseline PKR gene expression in EVRs $(3.810 \pm 0.7026, \mathrm{n}=23)$ compared to controls $(1.805 \pm 0.4038$, $\mathrm{n}=12) ; \mathrm{p}=0.0580$. Nor is PKR significantly upregulated in nonEVRs $(5.763 \pm 3.150, \mathrm{n}=7)$ compared to controls (1.805 \pm $0.4038, \mathrm{n}=12) ; \mathrm{p}=0.1195$ and there is no significant difference

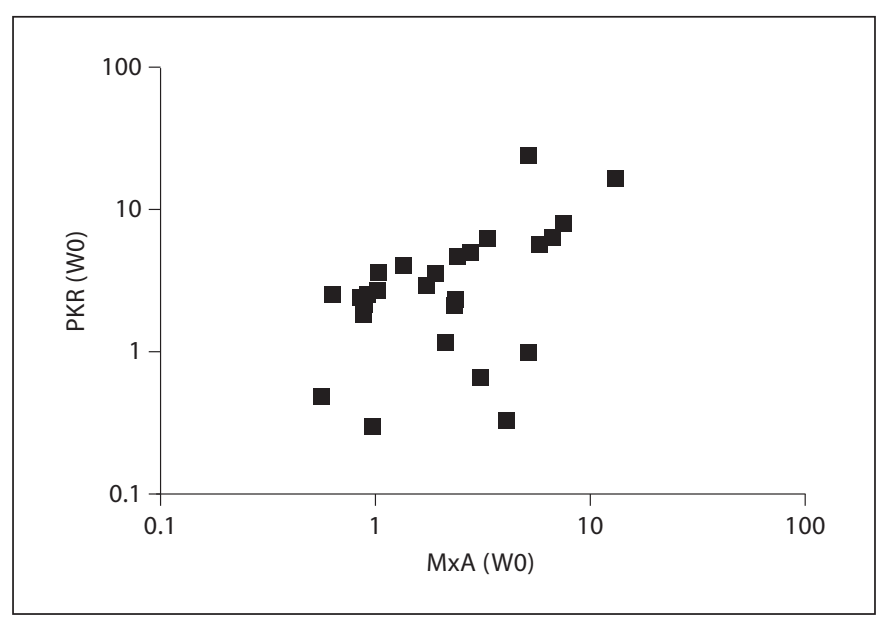

Fig. 3. Coordinate upregulation of $\mathrm{MxA}$ and $\mathrm{PKR}$ genes. MxA and PKR mRNA expression levels in PBMCs of 30 patients infected with HCV genotype 4 show a statistically significant positive correlation ( $\mathrm{p}=0.0002, \mathrm{r}=$ Pearson's correlation coefficient). W0 = Week 0 .

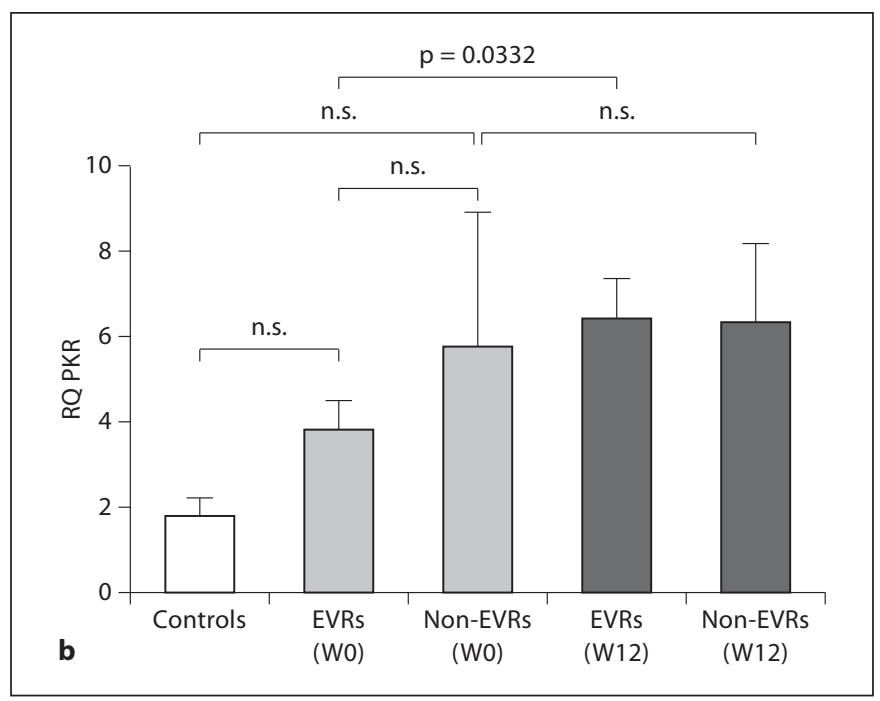

between EVRs and non-EVRs ( $p=0.3617)$. Significant PKR gene expression upregulation in EVRs at week 12 (W12) (6.402 \pm $0.9465, \mathrm{n}=23)$ compared to week 0 (W0) $(3.810 \pm 0.7026, \mathrm{n}=23)$; $\mathrm{p}=0.0332$. Non-EVRs do not show any significant upregulation of PKR gene expression at week $12(6.325 \pm 1.829, \mathrm{n}=7)$ compared to week $0(5.763 \pm 3.150, \mathrm{n}=7) ; \mathrm{p}=0.8799$. The results are expressed as means \pm SEM of relative quantitation $(\mathrm{RQ}=$ $\left.2^{-\Delta \Delta C T}\right)$. Bar $=$ Mean value.

pared between EVRs and non-EVRs by comparing the ratio week 12/week 0 in both groups; however, no significant difference was found ( $\mathrm{p}=0.478$; data not shown).

\section{p53 mRNA Expression in PBMCs}

p53 gene expression level was compared among healthy controls and untreated $\mathrm{HCV}$-infected patients. Patients showed higher baseline p53 gene expression in PBMCs compared to healthy controls ( $\mathrm{p}=0.0014$; fig. $5 \mathrm{a}$ ). Both EVRs and non-EVRs showed asignificant upregulation in p53 gene expression compared to healthy controls ( $\mathrm{p}=$ 0.002 and 0.004 , respectively) without a significant difference between EVRs and non-EVRs (fig. 5b). No increase was found in p53 mRNA expression level at week 12 compared to week 0 in both EVRs and non-EVRs (fig. 5b).

\section{Association between $p 53$ Gene Expression and}

Expression of ISGs

HCV-infected patients were classified into two groups according to the level of p53 gene expression; the first group was composed of patients having a less than 1.5fold increase in $\mathrm{p} 53$ gene expression compared to the control population $(\mathrm{p}=0.036)$ and the second group included 


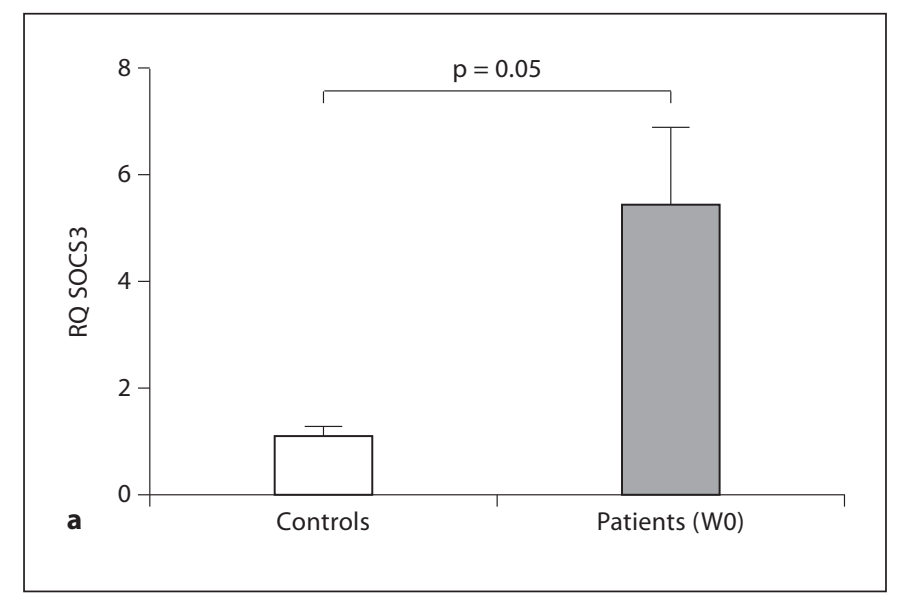

Fig. 4. SOCS3 mRNA expression in PBMCs before and during treatment. a SOCS3 gene was upregulated in HCV genotype 4-infected patients $(5.413 \pm 1.470, \mathrm{n}=21)$ compared to healthy controls $(1.097 \pm 0.1729, \mathrm{n}=10) ; \mathrm{p}=0.05$. b Baseline SOCS3 expression was upregulated in both EVRs $(6.706 \pm 1.966, \mathrm{n}=15)$ and non-EVRs $(2.181 \pm 0.5186, \mathrm{n}=6)$ compared to controls $(1.096 \pm$ $0.1731, \mathrm{n}=10) ; \mathrm{p}=0.0303$ and 0.0312 , respectively. There is no

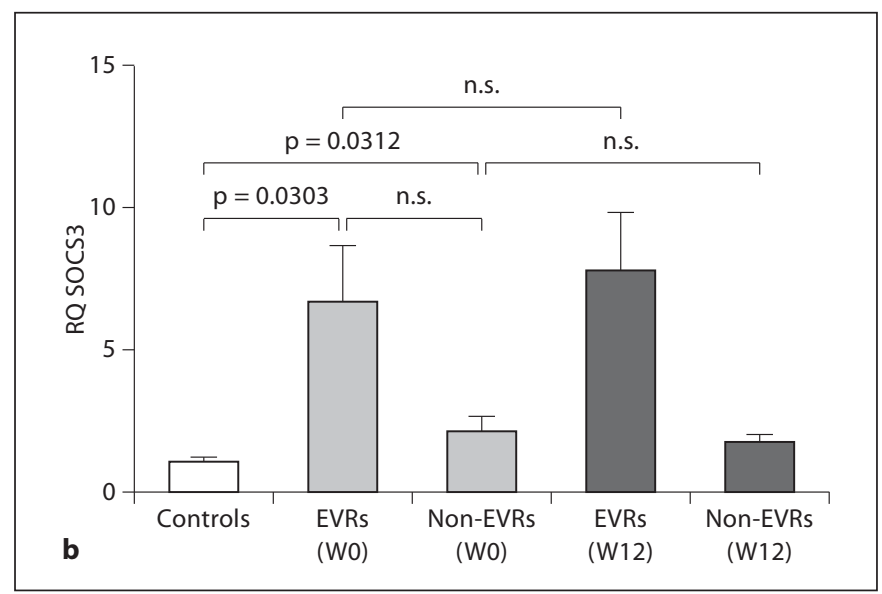

significant difference between EVRs and non-EVRs ( $\mathrm{p}=0.1701)$. Nor do EVRs and non-EVRs show any significant upregulation in SOCS3 mRNA expression levels at week 12 (W12) (7.829 \pm $2.059, \mathrm{n}=15$ and $1.765 \pm 0.2815, \mathrm{n}=6$, respectively) compared to week 0 (W0) $(6.706 \pm 1.966, \mathrm{n}=15$ and $2.181 \pm 0.5186, \mathrm{n}=6$, respectively); $\mathrm{p}=0.6963$ and 0.4969 , respectively. The results are expressed as means \pm SEM of relative quantitation $\left(R Q=2^{-\Delta \Delta C T}\right)$. patients with a more than 1.5 -fold increase in their p53 gene expression level compared to the same control population $(\mathrm{p}<0.0001)$. Baseline MxA and PKR gene expression levels were compared between both groups. In the first group with a relatively low p53 gene expression, neither MxA nor PKR gene expression was significantly upregulated in $\mathrm{HCV}$ patients compared to controls, with $\mathrm{p}=$ 0.063 and 0.066 , respectively (fig. $5 c$ ). In the second group with a high $\mathrm{p} 53$ gene expression level, both $\mathrm{MxA}$ and $\mathrm{PKR}$ genes were found to be significantly upregulated compared to controls, with $\mathrm{p}=0.015$ and 0.034 , respectively (fig. 5d). Moreover, the existence of a correlation between p53 and MxA and PKR expression was studied and a nearly significant positive correlation between $\mathrm{p} 53$ and $\mathrm{PKR}$ baseline expression ( $\mathrm{p}=0.056, \mathrm{r}=0.312)$ and a nonsignificant correlation between p53 and MxA baseline expression ( $\mathrm{p}=0.38, \mathrm{r}=0.144$; data not shown) were found.

\section{Discussion}

Few studies have analyzed the baseline expression of ISGs in correlation to virologic response to treatment and the results were controversial [29-33]. However, for the time being, little is known about ISGs gene expression in HCV genotype 4 . The present study was mainly conducted on patients infected with HCV genotype 4. MxA but not PKR showed higher gene expression in untreated HCV genotype 4 patients compared to healthy controls both in EVRs and non-EVRs. This shows that the JAKSTAT pathway was activated in PBMCs of HCV genotype 4-infected patients independent of virologic response, which is concordant with other studies [34]. These baseline results further support previous studies regarding the great sensitivity of MxA in measuring the biological activity of both endogenous and exogenous IFN- $\alpha[35$, 36]. Although a coordinate upregulation of baseline expression of both MxA and PKR in patients was observed in the present study, patients did not show a significant increase in PKR gene expression compared to healthy individuals. This finding could be explained either by a virus-related poor IFN induction or a virus-related attenuation of ISGs transcription. In fact, HCV core protein has been reported to downregulate the transcription of IFNinducible antiviral genes as a mechanism of escape to the host immune system [37]. To our knowledge, the viral effect of HCV genotype 4 on the transcription of the different ISGs has not been previously investigated and could be a potential topic for further investigations.

The present gene expression study has been performed on PBMCs for several reasons. Besides the fact that PBMCs have been shown to be a reservoir for HCV replication [34], PBMCs are strong IFN producers [38], and stronger IFN producers than hepatocytes [39]. Moreover, the use of 

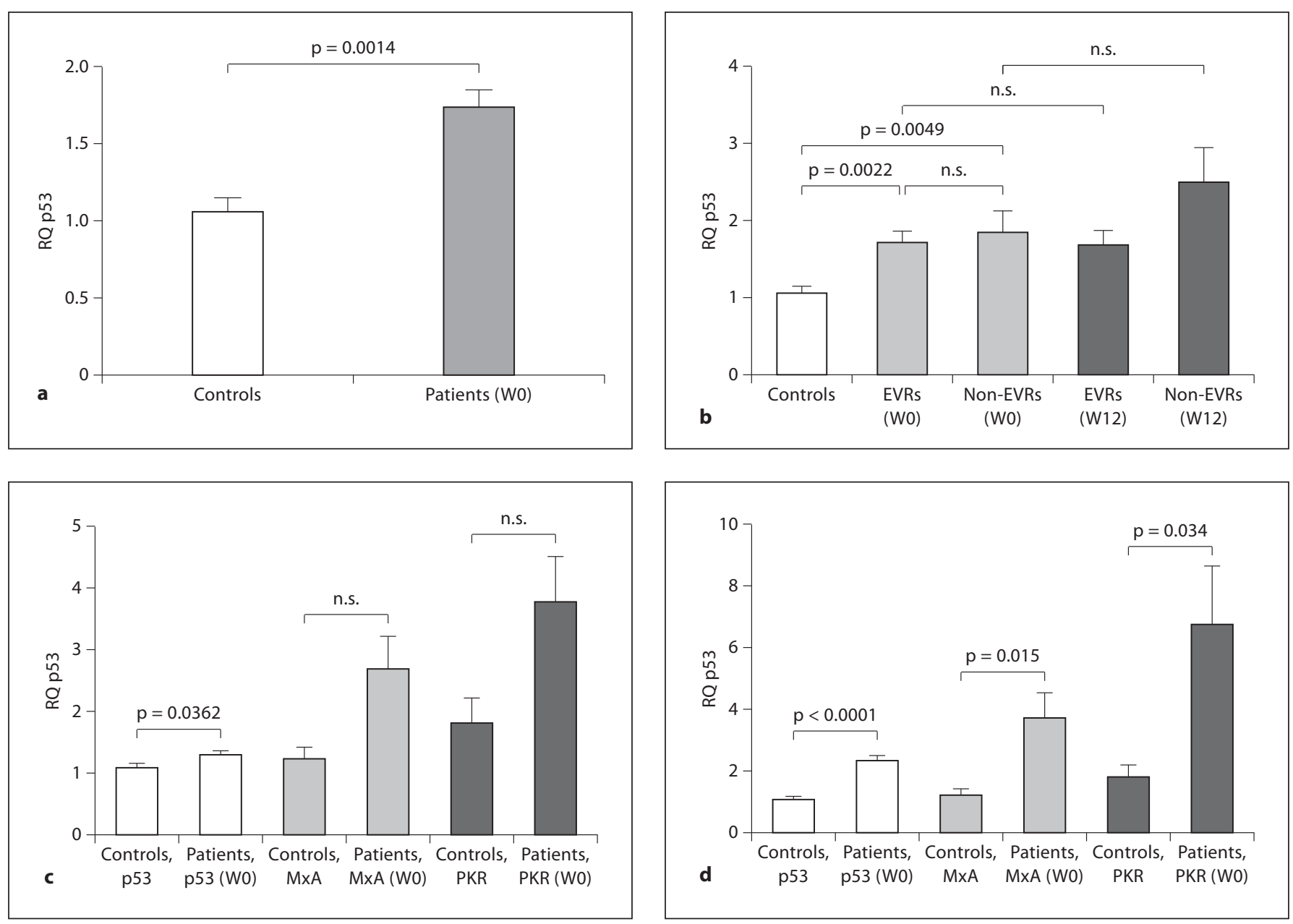

Fig. 5. p53 mRNA expression in PBMCs of HCV patients and correlation with ISG expression. a Significant upregulation of p53 mRNA expression in patients $(1.736 \pm 0.1156, \mathrm{n}=38)$ compared to controls $(\mathrm{p}=0.0014)$. b Baseline p53 expression was upregulated in both EVRs $(1.722 \pm 0.1383, \mathrm{n}=26)$ and non-EVRs $(1.846$ $\pm 0.2796, \mathrm{n}=9)$ compared to controls $(1.060 \pm 0.0923, \mathrm{n}=14)$ $\mathrm{p}=0.0022$ and 0.0049 , respectively. There is no significant difference between EVRs and non-EVRs $(p=0.6676)$. At week $12(\mathrm{~W} 12)$ of therapy, neither EVRs nor non-EVRs show any significant upregulation of p53 mRNA expression $(1.693 \pm 0.1762, \mathrm{n}=26$ and $2.502 \pm 0.4419, \mathrm{n}=9$, respectively) compared to week 0 (1.722 \pm $0.1383, \mathrm{n}=26$ and $1.846 \pm 0.2796, \mathrm{n}=9$, respectively); $\mathrm{p}=0.8959$ and 0.2281 , respectively. $\mathrm{c}$ Patients with $<1.5$-fold increases in $\mathrm{p} 53$

peripheral blood in the present study had the advantage of analyzing both baseline gene expression and the changes in gene expression during therapy of both MxA and PKR.

A major finding of this study was that patients who achieved an early virologic response to combination therapy had a large increase in both MxA and PKR mRNA levels in PBMCs after 12 weeks of therapy. Non-EVRs, in

gene expression level $(1.292 \pm 0.06101, \mathrm{n}=22)$ compared to healthy controls $(1.060 \pm 0.0923, \mathrm{n}=14)(\mathrm{p}=0.0362)$ do not show any significant upregulation of $\mathrm{MxA}(2.671 \pm 0.5446, \mathrm{n}=22)$ or PKR (3.780 $\pm 0.7299, \mathrm{n}=22)$ compared to controls $(1.217 \pm$ $0.1919, \mathrm{n}=12$, and $1.805 \pm 0.4038, \mathrm{n}=12$, respectively); $\mathrm{p}=0.063$ and 0.066 , respectively. d Patients with high-level p53 gene expression, i.e. $>1.5$-fold increase $(2.347 \pm 0.1676, \mathrm{n}=16)$ compared to healthy controls $(1.060 \pm 0.0923, \mathrm{n}=14)(\mathrm{p}<0.0001)$ show a significant upregulation of both $\mathrm{MxA}(3.711 \pm 0.8182, \mathrm{n}=16)$ and $\operatorname{PKR}(6.757 \pm 1.885, \mathrm{n}=16)$ compared to controls $(1.217 \pm 0.1919$, $\mathrm{n}=12$, and $1.805 \pm 0.4038, \mathrm{n}=12$, respectively); $\mathrm{p}=0.015$ and 0.034 , respectively. The results are expressed as means \pm SEM of relative quantitation $\left(\mathrm{RQ}=2^{-\Delta \Delta \mathrm{CT}}\right)$. Bar $=$ Mean value.

contrast, showed no significant change in PKR gene expression and only a moderate upregulation of MxA gene expression at week 12 . These results are in agreement with a previous study that showed that the global induction of ISGs in cultured PBMCs was significantly greater in responders than in nonresponders and in white patients compared with black patients [40]. Moreover, these find- 
ings are concordant with those of a recent study conducted on genotype 1 , where a microarray analysis demonstrated that changes in gene expression in PBMCs during pegylated IFN and ribavirin therapy could distinguish responders from nonresponders [41]. To our knowledge, the present study is the first to analyze the changes in ISGs expression during therapy in HCV genotype 4-infected patients.

Based on recent findings that high pretreatment SOCS3 gene expression positively correlated with nonresponse to therapy in genotype 1-infected patients [23-25], the present study aimed at investigating the role of SOCS3 gene expression in resistance to therapy in HCV genotype 4-infected patients since no data concerning this genotype have been reported yet. In the present study, the overall pretreatment SOCS3 mRNA level was higher in patients than in healthy controls and this could be explained by the previously reported role of SOCS3 in the negative regulation of the JAK-STAT pathway [20], which has been demonstrated to be activated in the patients studied. Although the baseline SOCS3 mRNA expression of EVRs showed a tendency to increase compared to nonEVRs, this increase was statistically nonsignificant. The absence of increase in SOCS3 mRNA level in non-EVRs compared to EVRs pleads against the implication of SOCS3 in resistance to IFN-based therapy in HCV genotype 4 -infected patients. Thus, the role of SOCS3 in resistance to therapy could be genotype dependent. This hypothesis is in agreement with the recent findings that SOCS3 expression level induced by HCV infection is higher in genotype 1 compared to genotype $2[21,25]$. Furthermore, changes in SOCS3 mRNA expression during therapy showed different results in genotypes 1 and 4. In fact, the present study showed that SOCS3 mRNA level after 12 weeks of therapy was comparable to the pretreatment level, whereas a recent study conducted on genotype 1 showed an important decrease in SOCS3 expression in response to IFN therapy in responders compared to nonresponders [42]. Moreover, this same study showed that pretreatment hepatic SOCS3 mRNA expression was higher in responders than in nonresponders, which contradicts other studies also conducted on genotype 1 [23-25]. This discrepancy in results could be explained by a genetic variability in SOCS3 since a genetic polymorphism in the SOCS3 gene was reported to influence the level of SOCS3 expression and IFN treatment outcome in chronic hepatitis C [23]. So far, genetic polymorphism in the SOCS3 gene has not been studied in genotype 4 and needs further investigations.

To our knowledge, the present study is the first to investigate the role of p53 in antiviral defense in HCV-in- fected human patients. Baseline expression of p53 mRNA in PBMCs of HCV patients was found to be significantly upregulated compared to healthy controls, which further confirms that HCV belongs to the viruses that upregulate the p53 gene. Based on the results of the present study, an association seems to exist between p53 gene expression and the expression of two important ISGs in antiviral defense, MxA and PKR. Interestingly, a low p53 expression was not accompanied by an upregulation of MxA and PKR genes, whereas these two genes were significantly upregulated in patients with strong p53 expression. Although a nearly significant positive correlation was found at least between p53 and PKR expression ( $p=0.056$ ), further evaluation of these findings in a larger patient cohort is needed. This association may support the previous in vitro studies regarding a possible contribution of p53 in antiviral defense.

In conclusion, we demonstrated in this study that patients infected with HCV genotype 4 who did not achieve an early virologic response to IFN- $\alpha$ /ribavirin combination therapy showed blunted changes in PKR gene expression but a significant MxA upregulation at week 12 of therapy compared to baseline expression of both these genes prior to therapy begin. EVRs showed an important induction of PKR and more marked MxA upregulation after 3 months of therapy compared to baseline. This is a further confirmation regarding the importance of studying the genetic response of ISGs in HCV patients under therapy for a more individualized assessment of response to treatment. Furthermore, SOCS3 gene expression does not seem to distinguish between responders and nonresponders in genotype 4. Finally, the association that seems to exist between $\mathrm{p} 53$ and MxA and PKR expression in HCV-infected patients further supports the recently suggested contribution of p53 in antiviral defense. Furthermore, studies using a larger number of patients would be very helpful in confirming our data.
References
1 WHO: World Health Organization. Hepati- tis C. WHO Fact Sheet 164, 2000
2 EMH: Egyptian Ministry of Health. Egyp- tian Ministry of Health Annual Report: 2007, Cairo 2007
-3 Nguyen MH, Keeffe EB: Prevalence and treat- ment of hepatitis $C$ virus genotypes 4,5 , and 6 . Clin Gastroenterol Hepatol 2005;3:S97-S101.
4 Abdel-Aziz F, Habib M, Mohamed MK, Ab- del-Hamid M, Gamil F, Madkour S, Mikhail NN, Thomas D, Fix AD, Strickland GT, An- war W, Sallam I: Hepatitis C virus (HCV) in- fection in a community in the Nile delta: Population description and HCV preva- lence. Hepatology 2000;32:111-115. 
5 Strader DB, Wright T, Thomas DL, Seeff LB: Diagnosis, management, and treatment of hepatitis C. Hepatology 2004;39:1147-1171.

-6 Manns MP, McHutchison JG, Gordon SC, Rustgi VK, Shiffman M, Reindollar R, Goodman ZD, Koury K, Ling M, Albrecht JK: Peginterferon alfa-2b plus ribavirin compared with interferon alfa-2b plus ribavirin for initial treatment of chronic hepatitis $\mathrm{C}$ : a randomised trial. Lancet 2001;358:958-965.

-7 Fried MW, Shiffman ML, Reddy KR, Smith C, Marinos G, Goncales FL Jr, Haussinger D, Diago M, Carosi G, Dhumeaux D, Craxi A, Lin A, Hoffman J, Yu J: Peginterferon alfa-2a plus ribavirin for chronic hepatitis $\mathrm{C}$ virus infection. N Engl J Med 2002;347:975-982.

-8 Hadziyannis SJ, Sette H Jr, Morgan TR, Balan V, Diago M, Marcellin P, Ramadori G, Bodenheimer H Jr, Bernstein D, Rizzetto M, Zeuzem S, Pockros PJ, Lin A, Ackrill AM: Peginterferon-alpha2a and ribavirin combination therapy in chronic hepatitis C: a randomized study of treatment duration and ribavirin dose. Ann Intern Med 2004;140: 346-355.

-9 Samuel CE: Antiviral actions of interferons. Clin Microbiol Rev 2001;14:778-809, table of contents.

10 Stark GR, Kerr IM, Williams BR, Silverman RH, Schreiber RD: How cells respond to interferons. Annu Rev Biochem 1998;67:227264.

11 Staeheli P, Pitossi F, Pavlovic J: Mx proteins: GTPases with antiviral activity. Trends Cell Biol 1993;3:268-272.

-12 Arnheiter H, Frese M, Kambadur R, Meier E, Haller O: Mx transgenic mice - animal models of health. Curr Top Microbiol Immunol 1996;206:119-147.

$\checkmark 13$ Simon A, Fah J, Haller O, Staeheli P: Interferon-regulated $\mathrm{Mx}$ genes are not responsive to interleukin-1, tumor necrosis factor, and other cytokines. J Virol 1991;65:968-971.

14 Holzinger D, Jorns C, Stertz S, Boisson-Dupuis $\mathrm{S}$, Thimme R, Weidmann M, Casanova JL, Haller O, Kochs G: Induction of MxA gene expression by influenza A virus requires type I or type III interferon signaling. J Virol 2007;81:7776-7785.

15 Gilli F, Marnetto F, Caldano M, Sala A, Malucchi S, Capobianco M, Bertolotto A: Biological markers of interferon-beta therapy: comparison among interferon-stimulated genes MxA, TRAIL and XAF-1. Mult Scler 2006;12:47-57.

16 Clemens MJ, Elia A: The double-stranded RNA-dependent protein kinase PKR: structure and function. J Interferon Cytokine Res 1997; 17:503-524.

-17 Samuel CE: Mechanism of interferon action: phosphorylation of protein synthesis initiation factor EIf-2 in interferon-treated human cells by a ribosome-associated kinase processing site specificity similar to hemin-regulated rabbit reticulocyte kinase. Proc Natl Acad Sci USA 1979;76:600-604

- 18 Lee SB, Melkova Z, Yan W, Williams BR, Hovanessian AG, Esteban M: The interferon-induced double-stranded RNA-activated human $\mathrm{p} 68$ protein kinase potently inhibits protein synthesis in cultured cells. Virology 1993;192:380-385.

19 Kang JI, Kwon SN, Park SH, Kim YK, Choi SY, Kim JP, Ahn BY: PKR protein kinase is activated by hepatitis $C$ virus and inhibits viral replication through translational control. Virus Res 2009;142:51-56.

20 Krebs DL, Hilton DJ: SOCS proteins: negative regulators of cytokine signaling. Stem Cells 2001;19:378-387.

21 Persico M, Capasso M, Persico E, Svelto M, Russo R, Spano D, Croce L, La Mura V, Moschella F, Masutti F, Torella R, Tiribelli C, Iolascon A: Suppressor of cytokine signaling 3 (SOCS3) expression and hepatitis C virusrelated chronic hepatitis: insulin resistance and response to antiviral therapy. Hepatology 2007;46:1009-1015.

22 Bode JG, Ludwig S, Ehrhardt C, Albrecht U, Erhardt A, Schaper F, Heinrich PC, Haussinger D: IFN- $\alpha$ antagonistic activity of $\mathrm{HCV}$ core protein involves induction of suppressor of cytokine signaling-3. FASEB J 2003;17: 488-490.

23 Persico M, Capasso M, Russo R, Persico E, Croce L, Tiribelli C, Iolascon A: Elevated expression and polymorphisms of SOCS3 influence patient response to antiviral therapy in chronic hepatitis C. Gut 2008;57:507-515.

24 Walsh MJ, Jonsson JR, Richardson MM, Lipka GM, Purdie DM, Clouston AD, Powell EE: Non-response to antiviral therapy is associated with obesity and increased hepatic expression of suppressor of cytokine signalling 3 (SOCS-3) in patients with chronic hepatitis C, viral genotype 1 . Gut 2006;55:529-535.

25 Kim KA, Lin W, Tai AW, Shao RX, Weinberg E, De Sa Borges CB, Bhan AK, Zheng H, Kamegaya Y, Chung RT: Hepatic SOCS3 expression is strongly associated with non-response to therapy and race in HCV and HCV/HIV infection. J Hepatol 2009;50:705711.

26 Takaoka A, Hayakawa S, Yanai H, Stoiber D, Negishi H, Kikuchi H, Sasaki S, Imai K, Shibue T, Honda K, Taniguchi T: Integration of interferon- $\alpha / \beta$ signalling to $p 33$ responses in tumour suppression and antiviral defence. Nature 2003;424:516-523.

27 Dharel N, Kato N, Muroyama R, Taniguchi H, Otsuka M, Wang Y, Jazag A, Shao RX, Chang JH, Adler MK, Kawabe T, Omata M: Potential contribution of tumor suppressor p53 in the host defense against hepatitis $\mathrm{C}$ virus. Hepatology 2008;47:1136-1149.

28 Munoz-Fontela C, Macip S, Martinez-Sobrido L, Brown L, Ashour J, Garcia-Sastre A, Lee SW, Aaronson SA: Transcriptional role of p53 in interferon-mediated antiviral immunity. J Exp Med 2008;205:1929-1938.

29 Chen L, Borozan I, Feld J, Sun J, Tannis LL, Coltescu C, Heathcote J, Edwards AM, McGilvray ID: Hepatic gene expression discriminates responders and nonresponders in treatment of chronic hepatitis $\mathrm{C}$ viral infection. Gastroenterology 2005; 128:14371444.

30 Feld JJ, Nanda S, Huang Y, Chen W, Cam M, Pusek SN, Schweigler LM, Theodore D, Zacks SL, Liang TJ, Fried MW: Hepatic gene expression during treatment with peginterferon and ribavirin: identifying molecular pathways for treatment response. Hepatology 2007;46:1548-1563.

31 Sarasin-Filipowicz M, Oakeley EJ, Duong FH, Christen V, Terracciano L, Filipowicz $\mathrm{W}$, Heim MH: Interferon signaling and treatment outcome in chronic hepatitis C. Proc Natl Acad Sci U S A 2008;105:70347039 .

32 Gerotto M, Dal Pero F, Bortoletto G, Realdon S, Ferrari A, Boccato S, Alberti A: Pkr gene expression and response to pegylated interferon plus ribavirin therapy in chronic hepatitis C. Antivir Ther 2004;9:763-770.

- 33 MacQuillan GC, Mamotte C, Reed WD, Jeffrey GP, Allan JE: Upregulation of endogenous intrahepatic interferon stimulated genes during chronic hepatitis $\mathrm{C}$ virus infection. J Med Virol 2003;70:219-227.

34 Pham TN, Macparland SA, Coffin CS, Lee SS, Bursey FR, Michalak TI: Mitogen-induced upregulation of hepatitis $C$ virus expression in human lymphoid cells. J Gen Virol 2005;86:657-666.

- 35 Chieux V, Hober D, Harvey J, Lion G, Lucidarme D, Forzy G, Duhamel M, Cousin J, Ducoulombier H, Wattre P: The MxA protein levels in whole blood lysates of patients with various viral infections. J Virol Methods 1998;70:183-191.

- 36 Roers A, Hochkeppel HK, Horisberger MA, Hovanessian A, Haller O: MxA gene expression after live virus vaccination: a sensitive marker for endogenous type I interferon. J Infect Dis 1994;169:807-813.

37 de Lucas S, Bartolome J, Carreno V: Hepatitis $\mathrm{C}$ virus core protein down-regulates transcription of interferon-induced antiviral genes. J Infect Dis 2005;191:93-99.

- 38 Colonna M, Krug A, Cella M: Interferonproducing cells: on the front line in immune responses against pathogens. Curr Opin Immunol 2002;14:373-379.

- 39 Mihm S, Frese M, Meier V, Wietzke-Braun P, Scharf JG, Bartenschlager R, Ramadori G: Interferon type I gene expression in chronic hepatitis C. Lab Invest 2004;84:1148-1159.

- 40 He XS, Ji X, Hale MB, Cheung R, Ahmed A, Guo Y, Nolan GP, Pfeffer LM, Wright TL, Risch N, Tibshirani R, Greenberg HB: Global transcriptional response to interferon is a determinant of HCV treatment outcome and is modified by race. Hepatology $2006 ; 44$ : 352-359.

41 Taylor MW, Tsukahara T, Brodsky L, Schaley J, Sanda C, Stephens MJ, McClintick JN, Edenberg HJ, Li L, Tavis JE, Howell C, Belle $\mathrm{SH}$ : Changes in gene expression during pegylated interferon and ribavirin therapy of chronic hepatitis C virus distinguish responders from nonresponders to antiviral therapy. J Virol 2007;81:3391-3401.

42 Huang Y, Feld JJ, Sapp RK, Nanda S, Lin JH, Blatt LM, Fried MW, Murthy K, Liang TJ: Defective hepatic response to interferon and activation of suppressor of cytokine signaling 3 in chronic hepatitis C. Gastroenterology 2007;132:733-744. 